\title{
Condensed tannins and gastro-intestinal parasites in sheep
}

\author{
A.L. MOLAN*, G.C. WAGHORN and W.C. McNABB \\ Nutrition Group, AgResearch Grasslands Research Centre, Private Bag 11008, \\ Palmerston North, New Zealand \\ ${ }^{*}$ To whom all correspondence should be addressed \\ Fax: +64-6-3518003, E. mail: molana@agresearch.cri.nz
}

\begin{abstract}
As the effectiveness of current anthelmintic drenches is being reduced by the emergence of drench resistance and significant production losses may still occur as a result of continuing larval challenge, strategies for nematode control should focus on preventing the build-up of infective larvae on pasture rather than treating the infection. This paper reports the effects of condensed tannins (CT) extracted from Lotus pedunculatus, Lotus corniculatus, sulla (Hedysarum coronarium) and sainfoin (Onobrychus viciifolia) on in vitro viability of eggs, first stage larvae (L1) and third stage larvae (L3) of the sheep nematode, Trichostrongylus colubriformis. When in vitro assays contained $\mathrm{CT}$ in a similar concentrations to that in the digestive tract of sheep fed these forages, the CT reduced the development of eggs to L3 larvae as well as the proportion of eggs hatching. The CT also reduced the development of L1 larvae to L3 larvae and decreased the motility of L3 larvae when assessed by the larval migration inhibition assay and this may reduce their infective capacity in vivo. If these forages are fed to grazing sheep, then it may be possible to reduce contamination of pasture with infective larvae and reduce our dependence on anthelmintics as the principal method for controlling internal parasites.
\end{abstract}

Keywords: condensed tannins, drench resistance, egg hatching, larval development, Lotus, parasites, sainfoin, sulla, Trichostrongylus colubriformis

\section{Introduction}

Internal parasites represent a significant economic burden to the animal industries in New Zealand. Proprietary anthelmentic drenches, the current means of internal parasite control, cost New Zealand farmers millions of dollars every year. However, of greater importance than cost is the development of parasite resistance to proprietary anthelmentic drenches (Waller 1994), which has been reported in sheep, goats and cattle in New Zealand (Schetter et al. 1989; Vlassoff et al. 1994) and the increasing concern about the anthelmintic residues in animal products (Sykes et al. 1992).
Alternative strategies for the control of internal parasites are needed and one approach may be to include plants which contain condensed tannins (CT; proanthocyanidins) into the grazing rotation (Robertson et al. 1995). Condensed tannins are polyphenolic compounds found in the leaves and stems of a range of forage species (Barry \& Manley 1986; Waghorn et al. 1990; Terrill et al. 1992). Some have multiple benefits such as increasing the liveweight gain, the rate of wool growth and milk production (Wang et al. $1996 \mathrm{a}, \mathrm{b}$ ).

This research programme has measured the effect of purified CT extracted from several plant species on the egg hatching, larval development and larval motility of the sheep nematode, Trichostrongylus colubriformis under in vitro conditions.

\section{How do tannins affect internal parasites?}

Forages which contain CT, notably sulla (Hedysarum coronarium) and Lotus pedunculatus have been shown to significantly increase the growth rate of parasitised lambs relative to non-CT containing forages, in the absence of anthelmintics (Waghorn \& Niezen 1994; Niezen et al. 1995; Robertson et al. 1995). Infected lambs (Niezen et al. 1995, 1998) and deer (Hoskin 1998) exhibited significantly lower faecal egg counts and lower abomasal and intestinal worm burdens when fed sulla compared to their counterparts fed conventional forages without $\mathrm{CT}$.

Low concentrations of $\mathrm{CT}$ have been shown to protect plant proteins against rumen degradation and to increase protein flow to the small intestine where they can improve the supply and absorption of amino acids (Waghorn et al. 1987). It has been shown that animals given elevated planes of nutrition are better able to resist infection and disease. The expression of disease is more severe in animals having low protein intakes (Coop \& Holmes 1996) whereas high protein intakes have been shown to increase the resistance of sheep to Haemonchus contortus (Wallace et al. 1996) and T. colubriformis (Kambara et al. 1993). Hence dietary CT may benefit parasitised sheep by improving their protein nutrition which in turn may improve the animals' immune response to the infection. Alternatively, CT may affect parasites directly in the digestive tract. 


\section{Results of in vitro assays}

The egg hatch and larval development assays were carried out as described by Hubert \& Kerboeuf (1984, 1992) and were used to evaluate the effects of CT extracted from L. pedunculatus, L. corniculatus, sulla and sainfoin (Onobrychus viciifolia) on egg viability and larval development of $T$. colubriformis. In the egg hatch assay, the undeveloped eggs were collected from the faeces of experimentally-infected lambs and incubated with a range of CT concentrations $(0,50$, $100,200,400,600,800$ and $900 \mu \mathrm{g} / \mathrm{ml})$ in $200 \mu \mathrm{l}$ of distilled water in 96-well micro-titre plates. After incubation for 26 hours at $24^{\circ} \mathrm{C}$, the numbers of unhatched eggs and first stage larvae (L1) were counted and the proportion of eggs hatched (number of first stage larvae/number of eggs in medium) was calculated. It can be seen from Figure 1 and Table 1 that the proportion of eggs hatched decreased with increasing CT concentrations.

Eggs were incubated with a range of CT concentrations $(0,25,50,100,150,200,300,400$ and 500 $\mu \mathrm{g} / \mathrm{ml}$ ) in an artificial medium for 7 days at $24^{\circ} \mathrm{C}$ (larval development assay). CT from the four forages were able to disrupt the life cycle of $T$. colubriformis by inhibiting the development of the eggs to third stage larvae (L3) when CT concentrations were $200-400 \mu \mathrm{g} / \mathrm{ml}$ (Figure 2).

The sensitivity of the L1 larvae to CT was investigated by allowing the eggs to hatch in the absence of $\mathrm{CT}$, then exposing them to the same concentrations mentioned above for the reminder of the 7-day incubation period. At the end of incubation period, the numbers of $\mathrm{L} 1$, second stage larvae (L2) and L3 larvae were counted and the mean larval development was calculated. The CT reduced the development of both eggs and L1 larvae to the infective stage in a concentration dependent pattern and the eggs were significantly $(\mathrm{P}<0.01)$ more sensitive to the action of CT than L1 larvae (Figure 2 and Table 1).

The larval migration inhibition (LMI) assay (Rabel et al. 1994), which depends on the ability of the test materials to immobilise and inhibit the migration of the third stage larvae through nylon mesh sieves, was used to show that CT from the four forages had inhibitory effects against exsheathed (the larvae were exsheathed in sodium hypochlorite, Rabel et al. 1994) larvae of T. colubriformis (Figure 3 and Table 1). Condensed tannins from sainfoin had the highest activity, followed by CT from $L$. pedunculatus, sulla and $L$. corniculatus.
Figure 1 The effect of condensed tannins (CT) extracted from Lotus pedunculatus, Lotus corniculatus, sulla (Hedysarum coronarium) and sainfoin (Onbrychus vicifolia) on the proportion of Trichostrongylus colubriformis eggs hatching in vitro. Each point represents the mean of triplicates \pm SEM.

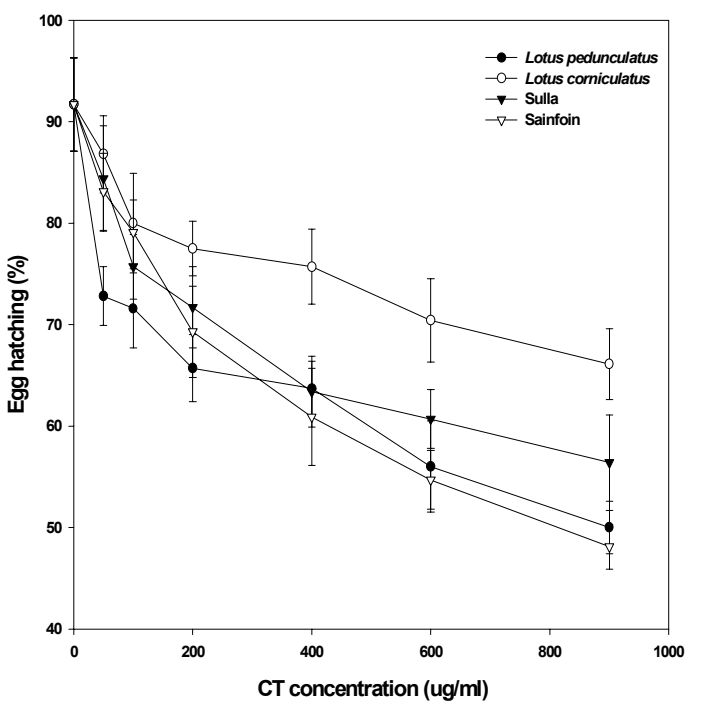

The inhibitory effects of condensed tannins (CT) extracted from Lotus pedunculatus, Lotus corniculatus, sulla (Hedysarum coronarium) and sainfoin (Onobrychus viciifolia) on egg hatching (EH), larval development (LD; L1 larvae) and larval viability of Trichostrongylus colubriformis in vitro. Data are expressed as: $\mathrm{EH}, \%$ of eggs not hatched; LD,\% of L1 larvae which did not develop to L3 larvae and LMI, \% of immobilised L3 larvae. Data are means and standard errors.

CT concentrations in media

\begin{tabular}{lcccccc} 
& \multicolumn{8}{c}{ CT concentrations in media } \\
& $-------~$ & $200 \mu \mathrm{g} / \mathrm{ml}$ & ----- & ----- & $400 \mu \mathrm{g} / \mathrm{ml}$ & ------- \\
& $\mathrm{EH}$ & LD & LMI & EH & LD & LMI \\
\hline L. pedunculatus & $34 \pm 3.3$ & $86 \pm 1.5$ & $21 \pm 1.4$ & $37 \pm 2.7$ & $91 \pm 1.4$ & $34 \pm 2.1$ \\
L. corniculatus & $23 \pm 2.7$ & $82 \pm 2.6$ & $15 \pm 2.0$ & $24 \pm 3.7$ & $87 \pm 1.3$ & $21 \pm 1.7$ \\
Sulla & $28 \pm 4.0$ & $83 \pm 2.4$ & $18 \pm 1.7$ & $36 \pm 3.5$ & $89 \pm 1.3$ & $27 \pm 2.3$ \\
Sainfoin & $31 \pm 4.5$ & $86 \pm 1.4$ & $32 \pm 1.4$ & $39 \pm 4.8$ & $96 \pm 0.7$ & $39 \pm 1.2$ \\
\hline
\end{tabular}

Table 1 summarises the effects of the three assays for two concentrations of CT. At $400 \mu \mathrm{g} / \mathrm{ml}$, CT from all the forages significantly inhibited $(\mathrm{P}<0.001) \mathrm{L} 1$ larvae from attaining full development to L3 larvae and L3 larvae $(\mathrm{P}<0.001)$ from passing through the sieves than at $200 \mu \mathrm{g} / \mathrm{ml}$.

\section{Practical implications}

This study showed that CT extracted and purified from L. pedunculatus , L. corniculatus, sulla and sainfoin 
Figure 2 The effect of condensed tannins (CT) extracted from Lotus pedunculatus, Lotus corniculatus, sulla (Hedysarum coronarium) and sainfoin (Onbrychus vicifolia) on the development of eggs and first larval stage of Trichostrongylus colubriformis into infective larvae in vitro. Each point represents the mean of duplicate incubations \pm SEM.
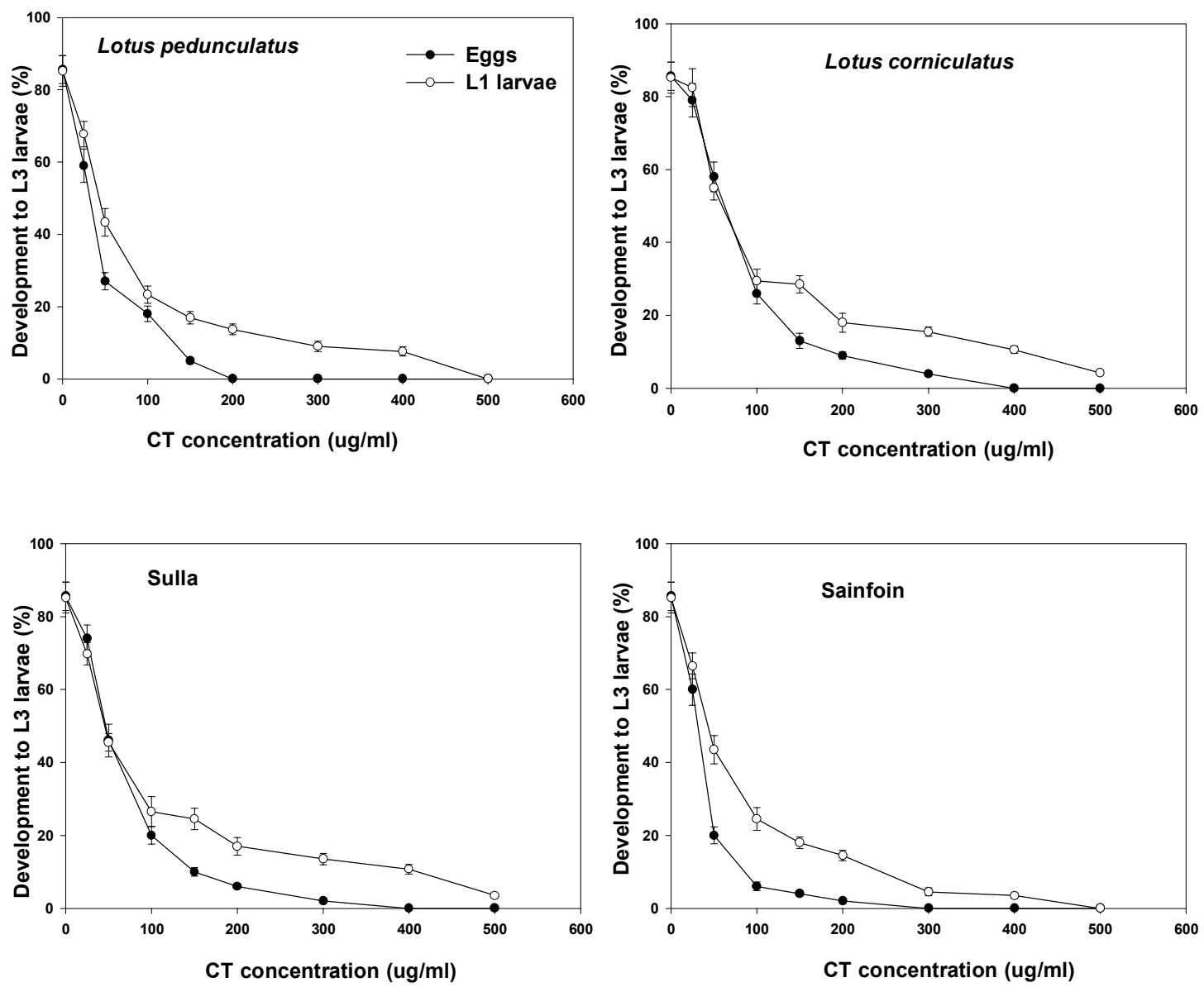

have the ability to inhibit the in vitro development of eggs and first stage (L1) larvae of T. colubriformis to L3 larvae. Applying results from this study to a practical situation suggests that CT may be able to break the life cycle of nematodes and may be able to reduce the contamination of pastures with viable eggs. Reduced numbers of infective larvae on pasture may lower our dependence on anthelmintics as the principal method for parasite control.

In contrast to anthelmintic drugs which are absorbed from the digestive tract (Sanyal et al. 1995), CT are not absorbed (Terrill et al. 1994) and leave the body with the faeces. This means that the eggs shed by the worms will be exposed to the effect of CT throughout their development. The concentrations of CT used in these assays are within the range of free CT (about $200-1000 \mu \mathrm{g} / \mathrm{ml}$ ) present in abomasal and duodenal

digesta and faeces of sheep fed CT-containing forages (Terrill et al. 1994).

This study has shown that $\mathrm{CT}$ are less potent as inhibitors of larval motility than larval development. For example $400 \mu \mathrm{g} / \mathrm{ml} \mathrm{CT}$ from each of the four forages inhibited only $21-39 \%$ of exsheathed L3 larvae from passing through nylon mesh sieves (LMI assay; Table 1). At the same concentration, CT inhibited 24$39 \%$ of egg hatching and $100 \%$ of egg development to L3 larvae. When L1 larvae were exposed to $400 \mu \mathrm{g} / \mathrm{ml}$ $87-96 \%$ did not develop to L3 larvae. This indicates that L3 larvae may not be the ideal stage for testing the sensitivity to CT, possibly because L3 larvae and eggs are the only non-feeding stages of the life cycle of $T$. colubriformis. Consequently, the results of the LMI assay may be of less importance than results of the LD assay. Future work should use eggs, L1 and L2 larvae to 
test materials able to inhibit the development of these stages to L3 larvae.

This study compared CT extracted from the four forages and indicated small differences in their activity against $T$. colubriformis larvae, with sainfoin being the most active followed by $L$. pedunculatus, sulla and $L$. corniculatus. The cause of differences between CT extracted from these forages is not known, but they do differ in molecular weight and structure (Foo et al. 1996, 1997). None of these forages are used widely in New Zealand and they require specialist establishment and management (Waghorn et al. 1998).

Figure 3 The effect of condensed tannin (CT) purified from Lotus pedunculatus, Lotus corniculatus, sulla (Hedysarum coronarium) and sainfoin (Onbrychus vicifolia) on larval migration inhibition (\% immobility) of Trichostrongylus colubriformis larvae in vitro. Each point represents the mean of quadruplicates \pm SEM.

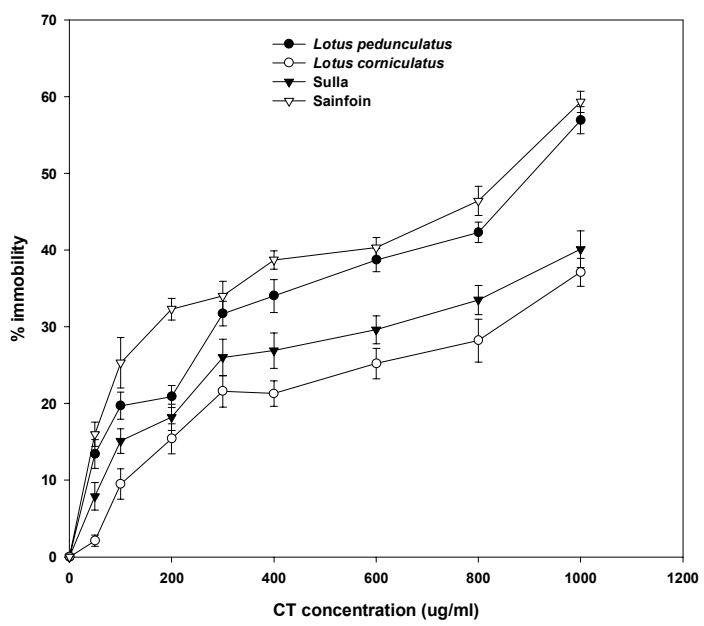

\section{Conclusions}

In addition to the other benefits of CT for ruminant nutrition, the in vitro results presented here suggest that CT may also be able to disrupt the life cycle of nematodes by reducing the egg viability and larval development. If CT are able to affect helminth parasites through several routes, they offer excellent opportunities for reducing our dependence on proprietary anthelmintic drenches. However, further research will be needed to evaluate the effect of CT or CT-containing forages on larval development under field conditions.

\section{ACKNOWLEDGEMENTS}

The authors acknowledge financial assistance provided by Wools of New Zealand for supporting Dr. Molan.

\section{REFERENCES}

Barry, T.N.; Manley, T.R. 1986. Interrelationships between the concentrations of total condensed tannins, free condensed tannins and lignin in Lotus spp. and their possible consequences in ruminant nutrition. Journal of the science of food and agriculture 37: 248-254.

Coop, R.L.; Holmes, P.H. 1996. Nutrition and parasite interaction. International journal for parasitology 26: 951-962.

Foo, L.Y.; Newman, R.; Waghorn, G.C.; McNabb, W.C.; Ulyatt, M.J. 1996. Proanthocyanidins from Lotus corniculatus. Phytochemistry 41: 617-621.

Foo, L.Y.; McNabb, W.C.; Waghorn, G.C.; Ulyatt, M.J. 1997. Proanthocyanidins from Lotus pedunculatus. Phytochemistry 45: 1689-1696.

Hoskin, S.O. 1998. Internal parasitism and growth of farmed deer fed different forage species. $\mathrm{PhD}$ thesis, Massey University, Palmerston North, New Zealand.

Hubert, J.; Kerboeuf, D. 1984. A new method for culture of larvae used in diagnosis of ruminant gastrointestinal strongylosis: comparison with faecal cultures. Canadian journal of comparative medicine 48: 63-71.

Hubert, J.; Kerboeuf, D. 1992. A microlarval development assay for the detection of anthelmintic resistance in sheep nematodes. The veterinary record 130: 442-446.

Kambara, T.; McFarlane, R.G.; Abell, T.T.; McAnulty, R.W.; Sykes, A.R. 1993. The effect of age and dietary protein on the immunity and resistance in lambs vaccinated with Trichostrongylus colubriformis. International journal for parasitology 23: 471-467.

Niezen, J.H.; Waghorn, T.S.; Charleston, W.A.G. 1998. Establishment and fecundity of Ostertagia circumcincta and Trichostrongylus colubriformis in lambs fed lotus (Lotus pedunculatus) or perennial ryegrass (Lolium perenne). Veterinary parasitology 78: 13-21.

Niezen, J.H.; Waghorn, T.S.; Charleston, W.A.G.; Waghorn, G.C. 1995. Growth and gastrointestinal nematodes parasitism in lambs grazing lucerne (Medicago sativa) or sulla (Hedysarum coronarium) which contains condensed tannins. Journal of agricutural science, Cambridge 125: 281-289.

Rabel, B.; McGregor, R.; Douch, P.G.C. 1994. Improved bioassay for estimation of inhibitory effects of ovine gastrointestinal mucus and anthelmintics on nematode larval migration. International journal for parasitology 24: 671-676.

Robertson, H.A.; Niezen, J.H.; Waghorn, G.C.; Charleston, W.A.G.; Jinlong, M. 1995. The effect 
of six herbages on liveweight gain, wool growth and faecal egg count of parasitised ewe lambs. Proceedings of the New Zealand Society of Animal Production 55: 199-201.

Sanyal, P.K.; Knox, M.R.; Singh, D.K.; Hennessy, D.R.; Steel, J.W. 1995. Influence of diet on the kinetic disposition of fenbendazole in cattle and buffalo. International journal for parasitology 25: 12011205.

Scherrer, A.M.; Pomroy, W.E.; Charleston, W.A.G. 1989. A survey of anthelmintic resistance on ten goat farms in the Manawatu region in 1988. New Zealand veterinary journal 37: 148-149.

Sykes, A.R.; McFarlane, R.G.; Familton, A.S. 1992. Parasites, immunity and anthelmintic resistance. pp. 179-191. In: Progress in sheep and goat research. Ed. Speedy, A.W. Wallingford, CAB International.

Terrill, T.H.; Rowen, A.M.; Douglas, G.B.; Barry, T.N. 1992. Determination of extractable and bound CT concentrations in forage plants, protein concentrate meals and cereal grains. Journal of the science of food and agriculture 58: 312-329.

Terrill, T.H.; Waghorn, G.C.; Wooley, D.J.; McNabb, W.C.; Barry, T.N. 1994. Assay and digestion of ${ }^{14} \mathrm{C}$-labelled condensed tannin in the gastrointestinal tract of sheep. British journal of nutrition. 72: 467477.

Vlassoff, A.; McKenna, P.B. 1994. Nematode parasites of economic importance in sheep in New Zealand. New Zealand journal of zoology 21: 1-8.

Waghorn, G.C.; Douglas, G.B.; Niezen, J.H.; McNabb, W.C.; Foote, A.G. 1998. Forages with condensed tannins - their management and nutrition value for ruminants. Proceedings of the New Zealand Grassland Association 60: 89-98.
Waghorn, G.C.; Jones, W.T.; Shelton, I.D.; McNabb, W.C. 1990. Condensed tannins and the nutritive value of herbage. Proceedings of the New Zealand Grassland Association 51: 171-175.

Waghorn, G.C.; Ulyatt, M.J.; John, A.; Fisher, M.T. 1987. The effects of condensed tannins on the site of digestion of amino acids and other nutrients in sheep fed on Lotus corniculatus L. British journal of nutrition 57: 115-126.

Waghorn, T.S.; Niezen, J.H. 1994. Lamb growth and gastrointestinal nematode tolerance when grazing two fodder crops. New Zealand journal of zoology 21: 101 .

Wallace, D.S.; Bairden, K.; Ducan, J.L.; Fishwick, G.; Gill, M.; Holmes, P.H.; McKellar, Q.A.; Murray, M.; Parkin, J.J.; Stear, M. 1996. Influence of soybean meal supplementation on the resistance of Scottish blackface lambs to Haemonchosis. Research in veterinary science 60: 138-143.

Waller, P.J. 1994. The development of anthelmintic resistance in ruminant livestock. Acta tropica 56: 233-243.

Wang, Y.; Douglas, G.B.; Waghorn, G.C.; Barry, T.N.; Foote, A.G.; Purchas, R.W. 1996a. The effect of condensed tannins upon the performance of lambs grazing Lotus corniculatus and lucerne (Medicago sativa). Journal of agricultural science, Cambridge 126: 87-98.

Wang, Y.; Douglas, G.B.; Waghorn, G.C.; Barry, T.N.; Foote, A.G. 1996b. Effect of condensed tannins in Lotus corniculatus upon lactation performance in ewes. Journal of agricultural science, Cambridge 126: 353-362. 
